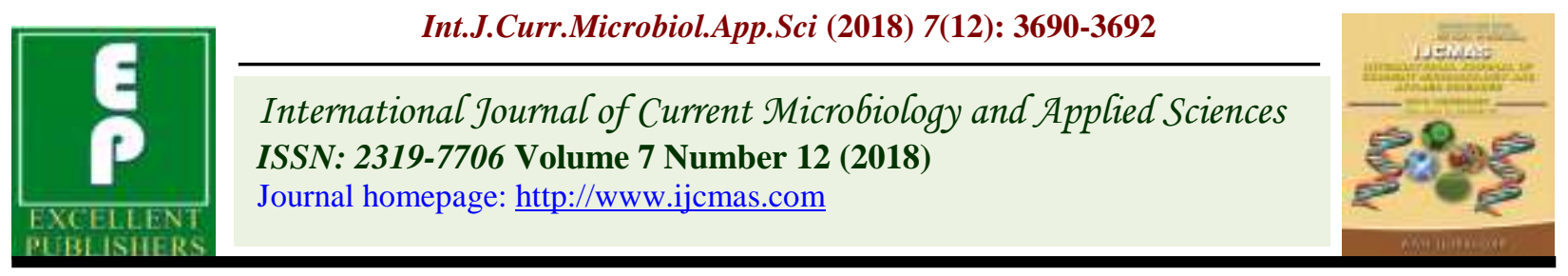

Case Study

https://doi.org/10.20546/ijcmas.2018.712.418

\title{
Avian Pox in a Blue Rock Pigeon- A Case Report
}

\author{
S. Ramesh ${ }^{1}$, C. Soundararajan ${ }^{2}$, J. Selvaraj ${ }^{3}$ and S. Subapriya ${ }^{*}$ \\ ${ }^{1}$ Centralised Instrumentation Laboratory, ${ }^{2}$ Department of Veterinary Parasitology, \\ ${ }^{3}$ Department of Veterinary Pathology, ${ }^{4}$ Centralised Clinical Laboratory, Madras Veterinary \\ College, TANUVAS, Chennai-600 007, Tamil Nadu, India \\ *Corresponding author
}

\section{A B S T R A C T}

\begin{tabular}{|l|}
\hline $\begin{array}{l}\text { Ke y w or d s } \\
\text { Avian Pox-Pigeons- } \\
\text { Cutaneous pox }\end{array}$ \\
\hline Article Info \\
\hline $\begin{array}{l}\text { Accepted: } \\
\text { 30 November } 2018 \\
\text { Available Online: } \\
\text { 10 December } 2018\end{array}$ \\
\hline
\end{tabular}

Keywords

Avian Pox-PigeonsCutaneous pox

10 December 2018
A blue rock pigeon which was found dead on the roadside at Chennai was subjected to a detailed necropsy. Numerous yellowish firm nodules were present on the unfeathered areas of skin while no diphtheritic lesions could be detected either in upper respiratory tract or digestive tract. Intracytoplasmic inclusions could be detected in the epidermal cells on histopathological examination. Intestinal contents revealed no endoparasites.

\section{Introduction}

Avipoxviruses (APVs), belonging to subfamily Chordopoxvirinae of the family Poxviridae, are the largest group of slowly spreading viruses affecting over 232 avian species including both domestic as well as free ranging birds viz., crow, sparrow, pigeons, partridges, mynahs, peafowls, eagle, hawk etc. (Joshi et al., 2012). The disease is transmitted mostly by mosquitoe bites and mites, and also through aerosol generated from infected birds, or by ingestion of contaminated feed or water. The disease occurs in two forms: cutaneous (dry form) and diphtheritic (moist form). The former develops as small papule, later progress to wart like scab on the unfeathered areas of skin while the latter develops a diphtheritic membrane in the upper respiratory and digestive tract (Mohan and Trevor, 2008). The most common method of transmission of dry form is through mosquito bites while that of wet form is through aerosol. Mortality and morbidity due to pox virus infection may be very high in pigeons (Tripathy, 1991). The diagnosis of a pox virus infection can be made based on the external clinical examination and gross lesions (Heuschele, 1986) but it is necessary to confirm the disease in the cutaneous form by the presence of characteristic Bollinger bodies in epithelial cells of epidermis by histopathologic analysis (Heuschele, 1986 and Randall and Reece, 1996). 
The present work is carried out to correlate the gross lesions with histological findings of inclusion bodies in epidermis of pigeon.

\section{Materials and Methods}

A blue rock pigeon was found dead on the road side of Chennai. A detailed necropsy was carried out. The lesions in various organs were recorded and the tissues which were collected in $10 \%$ formalin were processed by routine paraffin embedding method and stained by Haematoxylin and eosin for histopathological examination (Stevens and Wilson 1996). Intestinal contents were subjected to microscopic examination for presence of Endoparasites (Soulsby, 1982).

\section{Results and Discussion}

The bird was found to be emaciated. External examination revealed numerous firm yellowish nodules $(1-3 \mathrm{~cm}$ in diameter) on the unfeathered areas of skin namely beak, eyelids and feet while internal examination

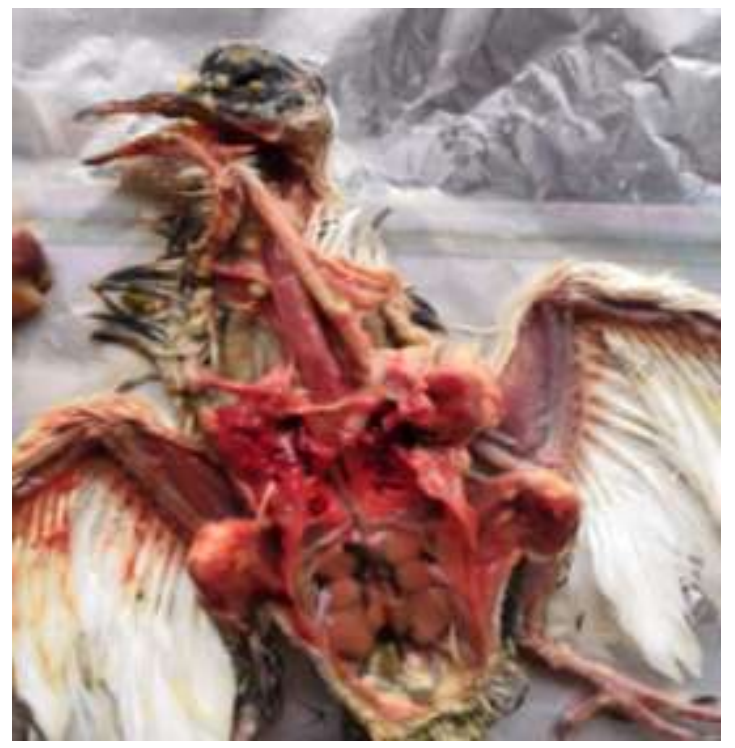

Fig.1 Pigeon-Pox - yellowish cutaneous lesions revealed no diphtheritic lesions either in the upper respiratory tract or digestive tract. However mild congestion was noticed in almost organs. Heart contained partially clotted blood (Fig. 1). The intestinal contents were yellowish in colour and watery in consistency which on microscopic examination revealed no endoparasites. Histological examination of skin lesions revealed viral intracytoplasmic inclusion bodies in epidermal cells (Fig. 2). The present findings were in accordance with the findings of Mohan and Fernandez (2008) who reported two cases of cutaneous form of pox infections in local pigeons. The birds were dehydrated and emaciated in nature. Several 0.5- $1 \mathrm{~cm}$ diameter coalescing, round, yellowish, rough and firm masses were found at the eyelids, beak, and the mouth, and some were superficially ulcerated. They also observed no diphtheritic lesions in affected birds as observed in the present study. Viral intracytoplasmic inclusions were demonstrated in epidermal cells as confirmed in the present case.

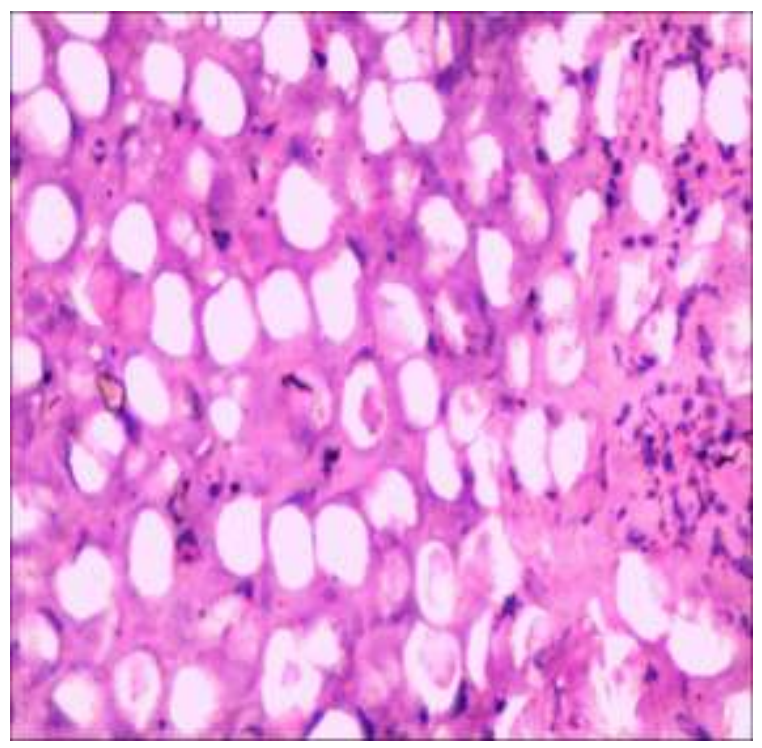

Fig.2 Pigeon-Pox - skin-intracytoplasmic inclusion bodies 


\section{References}

Heuschele, W.P. 1986. Infectious diseases. In Textbook of Zoo and wild animal medicine, $2^{\text {nd }}$ edn., Fowler, M.E. W.B. Saunders Company, Philadelphia, Pennsylvania, p. 57.

Joshi, S., Mudasir, M., Sharma, D. and Singh, R. 2012. Histopathological study of cutaneous form of Avipoxvirus infection in Jungle crow (Corvus macrorhynchos).Vet. World., 5(10): 628-630.

Mohan. M and Fernandez, T.F., 2008. A case report of Pigeon Pox-Histopathologic Diagnosis. Veterinary World. 1(4) : $117-118$

Randall, C.J., and Reece, R.L. (1996):
Integumentary system. In Textbook of Color atlas of avian histopathology, Randall, C.J. and Reece, R.L. MosbyWolfe, London, UK, p. 43.

Soulsby EJL. 1982. Helminths, arthropods and protozoa of domesticated animals, 7th edn. ELBS and Baillere Tindal, London

Stevens, A., Wilson, I.G. 1996. The haematoxylin and eosin. In: Bancroft JD, Stevens A (Eds) Theory and practice of histological techniques. Churchill Livingstone, New York, pp 99-112

Tripathy, D.N. 1991: Pox. In Textbook of Diseases of poultry, Calnek, B.W. Iowa State University Press, Ames, Iowa, p. 583.

\section{How to cite this article:}

Ramesh, S., C. Soundararajan, J. Selvaraj and Subapriya, S. 2018. Avian Pox in a Blue Rock Pigeon- A Case Report. Int.J.Curr.Microbiol.App.Sci. 7(12): 3690-3692.

doi: https://doi.org/10.20546/ijcmas.2018.712.418 